\title{
A Framework for Evaluating Alternate Institutional Arrangements for Fiscal Equalization Transfers
}

\author{
Anwar Shah
}

\begin{abstract}
Fiscal equalizations programs are fairly common features of intergovernmental fiscal relations in industrial countries. Some developing countries have also recently introduced these programs and still others are contemplating such programs. Institutional arrangements for fiscal equalization vary across countries with wide variations in the form and membership of the relevant decision making bodies. This paper provides a simple neo-institutional economics framework for assessing alternative institutional arrangements for their impacts on simplicity, transparency and objectivity of the equalization program as well as transaction costs for various parties involved.

Comparing institutional arrangements across different countries is a daunting task. The success of these arrangements depends upon a multitude of factors. The success of governance structures for fiscal matters may depend not only on the incentives regime associated with their inner structures but also their interactions with other formal and informal institutions in the country. This paper presents a simple framework to understand these incentives and interactions and draw implications for their impacts on transactions costs for the society as a whole and achievement of societal objectives. An application of these concepts to the specific case of institutional arrangements for fiscal equalization transfers are carried out and the predictions based upon the theory are compared to observed experiences in major federal countries. The paper demonstrates that the simple new institutional framework presented here has a significant power for predicting potential impacts. The paper concludes, both in theory and practice, that the case for independent grants commission to enhance the transparency, equity and accountability of the intergovernmental finance system is vastly exaggerated.
\end{abstract}

World Bank Policy Research Working Paper 3785, December 2005

The Policy Research Working Paper Series disseminates the findings of work in progress to encourage the exchange of ideas about development issues. An objective of the series is to get the findings out quickly, even if the presentations are less than fully polished. The papers carry the names of the authors and should be cited accordingly. The findings, interpretations, and conclusions expressed in this paper are entirely those of the authors. They do not necessarily represent the view of the World Bank, its Executive Directors, or the countries they represent. Policy Research Working Papers are available online at http://econ.worldbank.org. 


\title{
A Framework for Evaluating Alternate Institutional Arrangements for Fiscal Equalization Transfers
}

\author{
Anwar Shahi, World Bank<ashah@worldbank.org>
}

\section{Introduction}

Fiscal equalization programs are fairly common features of intergovernmental fiscal relations in industrial countries. Some developing countries have also recently introduced these programs and still others are contemplating such programs. Institutional arrangements for fiscal equalization vary across countries with wide variations in the form and membership of the relevant decision making bodies. For ease of analysis, these diverse arrangements can be broadly classified into five stylized models: (1) a central government ministry/agency; (2) independent agency (grants commission) reporting either to the executive or the legislature on a permanent or periodic basis; (3) intergovernmental forums including intergovernmental cum civil society forums; (4) national legislature; and (5) sub-national government forums. These arrangements have not yet received the attention that is due in view of their importance in creating a credible and stable fiscal transfers regime and only a handful of recent papers (Searle, 2004, Boex and Martinez-Vazquez, 2004) have documented these arrangements and provided commentaries on alternate regimes. This paper carries this work further by providing a simple neo-institutional economics framework for assessing alternative institutional arrangements for their impacts on simplicity, transparency and objectivity of the equalization program as well as transaction costs for various parties involved. The paper is organized as follows. Section 2 briefly discusses the goals for intergovernmental fiscal relations. It further highlights variety of institutional arrangements pursued by various countries to further these goals. Section 3 presents a simple framework to conduct a comparative evaluation of institutional arrangements. Section 4 presents a qualitative evaluation of alternate institutional arrangements with special emphasis on the Commonwealth Grants Commission of Australia. A concluding sections draws policy implications of this analysis.

\section{Goals and Alternate Models of Institutional Arrangements for Revenue Sharing and Equalization Transfers}

Institutional arrangements for fiscal transfers are typically structured to fulfill a number of objectives. These include both the process and program objectives. Program objectives seek to design a program that is consistent with general revenue sharing and/or equalization objectives. Further the design should be simple so that it is easily understood to forge a broader consensus, ownership and support. It should use uncontestable data and transfer funds in such a way to respect local autonomy while creating incentives environment that is compatible with accountability for results. These program objectives 
require a process of consultation with recipient governments that is open and transparent, conducive to consensus building and entails a relatively low cost of transactions for all parties concerned. The process should further aim to ensure that there is a wider public acceptance of the programs that are implemented.

While the above objectives are commonly shared, specific institutional arrangements structured to fulfill those objectives vary widely across countries. Nevertheless, to simplify matters for analysis, in the following we present five stylized groupings of these arrangements.

(a) Central/National Government Agency Model: This is the most commonly practiced model in both industrial and developing countries. A central agency typically, either the president or prime minister's office or the ministry of finance or home affairs or local government or planning (including planning commission) assume sole or shared responsibilities for policy making and implementation of a system of fiscal transfers including equalization transfers. A few country examples of such arrangements are reported below:

Office of the President: Kyrgyz Republic, Tanzania (Regional Administration and Local Government Unit)

Ministry of Finance: China, Italy (policy only), Kazakhstan. Netherlands (shared with the Ministry of Home Affairs), Poland, Switzerland, Ukraine

Ministry of Home Affairs/Interior: Italy (distribution of funds only), Netherlands (with Ministry of Finance), Philippines (Ministry of Interior and Local Government), South Korea (Ministry of Government Administration and Home Affairs)

Ministry of Local Government: Ghana (Ministry of Local Government and Rural Development), Zambia

Planning commission: India (for plan/capital grants)

Ministry of Public Administration: Japan (Ministry of Finance is consulted).

(b) National Legislature. In almost all countries with the single exception of China, national legislature must enact legislation to provide a legal basis for central-state-local transfers. Brazil, however, represent a unique case where 1988 Constitution specifies the pool and the broad criteria for revenue sharing transfers and the upper house of the national parliament (the Senate) serves as the primary decision making body for specifics of the formula as well as monitoring compliance. The Senate regulations spell out the specific distribution criteria for the state and municipal participation funds (see Shah, 1991). 


\section{(c) Intergovernmental Forums}

Intergovernmental forums facilitate consultations among various orders of government and to strike a balance among competing interests and mediate conflicts. In view of this such institutional arrangements are commonplace in federal countries. In some countries such as Australia and the Republic of South Africa where an independent agency has been assigned a strong role in intergovernmental fiscal relations, intergovernmental forums are also established to review and decide on independent agency recommendations. Among the industrial countries Canada and Germany and among developing countries Indonesia, Nigeria and Pakistan rely solely on intergovernmental forums for decisions on fiscal transfers. The following paragraphs highlight salient features of these institutional arrangements.

\section{Canada: Fiscal Arrangements Committee}

The primary legal responsibility for the design of fiscal transfers rests with the federal government (Ministry of Finance) and final approval with the national parliament. The Federal Government of Canada, nevertheless, places a strong emphasis on intergovernmental consultation and shared decision making on intergovernmental fiscal transfers. Federal-provincial fiscal arrangement committees play a pivotal role in providing substance to such dialogues (see Figure 1). The Federal-Provincial Relations Division in the Ministry of Finance provides a secretariat for these committees. Fiscal Arrangements Committee comprises federal and provincial finance and/or treasury officials concerned with fiscal transfers. They meet periodically but exchange information and comments on a continuing basis on all technical aspects of fiscal arrangements. The recommendations of this subcommittee is fed to the Continuing Committee of Officials on Fiscal and Economic Matters comprising federal and provincial deputy ministers of finance (or treasurers). This Committee is chaired by The Federal Deputy Minister of Finance and usually meets on a quarterly basis. The final recommendations of this Committee for further action are forwarded to regular (typically semi-annual) meetings of federal and provincial Ministers of Finance and/or Provincial Treasurers chaired by the Federal Minister of Finance. The fiscal equalization program is monitored and reviewed by these committees on a continuing basis with an intensive review every five years to suggest revisions for the enactment of new national legislation for the next five year period.

\section{Germany: Financial Planning Council}

The German federal system emphasizes sharing of responsibilities and joint decision making embodied in uniform federal legislation applicable to all landers (states). The upper house of the parliament, Bundesrat, with representation from lander governments, serves to strengthen a common approach. In fiscal relations, major decisions on the fraternal equalization transfers program are reached through a solidarity pact at a forum of federal and state leaders (presidents). Substantive inputs for reaching this pact come from the Financial Planning Council (Finanzplanungsrat) which establishes guidelines and recommendations for policy action on the financing of budgets in the short and 
medium term. The Council aims to reach agreement on fiscal policy coordination among federal and state governments. This Council comprises Federal Ministers of Finance and of Economics, the State Ministers responsible for Finance, four representatives of the municipalities (appointed by the Bundesrat based upon nominations by the municipal associations). The Council is chaired by the Federal Minister of Finance (see Spahn, 2001) and is required to meet at least twice a year.

\section{Indonesia: Regional Autonomy Advisory Board (DPOD)}

The Regional Autonomy Advisory Board (DPOD) serves as important intergovernmental forum in support of the Law No.22/1999 on Regional Governance and the Law No. 25/1999 on the Fiscal Balance between the Central Government and the Regions. The Board advises the President on all aspects of local government organization and finance issues. The Board is chaired by Minister of Home Affairs with the Minister of Finance serving as the Deputy Chair. Other members of this Board include, Secretary of State, Minister of Administrative Reform, Minister of Defense, Chairman of the National Development Planning Board (BAPENNAS), two representatives each of the Provinces, Kota (districts) and Kabupaten (towns) and one representative each of the associations of Provinces, Kota and Kabupaten (see Searle, 2004 for details and a critique). Technical work on fiscal matters including fiscal equalization grants is conducted by the Directorate General for Center-Region Fiscal Balance of the Ministry of Finance. Work on planning grants is carried out by the National Planning Board. The DPOD reviews the recommendations of the Ministry of Finance and the National Planning Board and makes final decisions. Monitoring and implementation responsibilities lie with the Ministry of Home Affairs.

\section{Nigeria: Revenue Mobilization, Allocation and Fiscal Commission}

The 1999 Constitution mandated the creation of the Revenue Mobilization, Allocation and Fiscal Commission to administer the federal-state-local fiscal transfers as well as provide advice on revenue mobilization at state and local levels. The Commission is chaired by the Federal Minister of Finance and comprises of Finance Commissioners or Accountant Generals from each state. The Commission meets each month to review financial flows (see Boex and Martinez-Vazquez, 2004).

\section{Pakistan: National Finance Commission}

The establishment every five years of a limited duration National Finance Commission is mandated under article 160 of the 1973 Constitution. The Constitution empowers the Commission to make recommendation to the President on the pool of revenues to be distributed as well as the allocation criteria. In addition, the Commission advises on the exercise of the borrowing powers by all levels of government. The Commission is chaired by the Federal Minister of Finance and comprises Provincial Ministers of Finance and other civil society members (e.g. legislators, scholars, experts, distinguished citizens etc) appointed by the President after consultation with provincial governors. The Federal Ministry of Finance serves as a secretariat for the Commission. The Commission makes 
its decision by consensus. If the Commission fails to reach a consensus on the formula for allocation of transfers as has been the case in recent years, then the formula that was operative in the previous five years is allowed to continue to operate until such time that a new consensus can be forged.

\section{(d) Independent Agency (Grants Commission) Model}

An independent agency is created usually by the central government to report either to the executive or legislature on a permanent or periodic basis. Australia pioneered this model by creating the Commonwealth Grants Commission in 1933 to assess claims made by states for financial assistance (special grants) under section 96 of the Constitution. This model has since then been adopted in several other countries most notably India, the Republic of South Africa and Uganda. In view of the growing popularity of this model of transfers governance, brief remarks on a sample of such commissions are presented in the following paragraphs.

\section{The Commonwealth Grants Commission (CGC) of Australia}

This commission was created in 1933 in response to dissatisfaction expressed by states especially a secession threat by Western Australia with the bilateral negotiations with the federal government on applications for special grants. The Commission in its 1936 report articulated that its assessment of the States' funding needs were to be based upon their capacity to raise revenue and any abnormal expenditure influences they faced. It stated that "special grants are justified when a state through financial stress from any cause is unable efficiently to discharge its functions as a member of the federation and should be determined by the amount of help found necessary to make it possible for that state by reasonable effort to function at a standard not appreciably below that of other states.” (source Australian Treasury, 2004). The Commission's mandate was vastly expanded in 1973 (The CGC Act, 1973) when it assumed responsibility for calculating the per capita relativities for allocation of federal general revenue sharing assistance to all states and the Northern Territory and the Territory of Cocos (Keeling) Islands; financing of works and services in the capital; determination of state entitlements for local government as well as determination of state grants to local governments. In 1975, state commissions relieved the CGC of its role in determining state grants to local governments. The determination of state entitlements for local governments was terminated by the Local Government Financial Assistance Act, 1986.The special grant program for selected states under section 9 of the Constitution was terminated in 1981/82 and replaced by program of assistance for all states and calculation of state relativities for general revenue grants that includes tax sharing, health and special grants on a five year basis with annual updates. The Commission consists of a chairperson and a maximum of five members appointed by the federal government in consultation with the states. The Commission has a permanent secretariat of about 60 (as of October 2004) staff members. The day-to day working of the Commission is handled by a Secretary and two assistant secretaries responsible for Expenditure Analysis Branch and Revenue, Budgets and Research Branch respectively. 
The Commission is constituted as an advisory body and empowered to conduct it business only within the purview of the terms of references provided by the Federal Minister of Finance and Administration. It does not have the powers to initiate and pursue inquiries on its own authority. In recent years, the main references have sought Commission's advice on per capita relativities for distributing, among the States and Territories, the pool of general revenue assistance made available by the Commonwealth. For this purpose, the Commission in 2004 applied a specific principle of fiscal equalization, which says that

State governments should receive funding from the pool of goods and services tax revenue and health care grants such that, if each made the same effort to raise revenue from its own sources and operated at the same level of efficiency, each would have the capacity to provide services at the same standard. (Commonwealth Grants Commission, 2004)

Another important matter on which the Commission has reported in recent years is the interstate distribution of general purpose grants for local government. Although the references are provided by the Minister for Finance and Administration, their content is usually decided in negotiations between the Commonwealth and the States, conducted largely through their treasuries. A formal mechanism for this purpose is the Heads of the Australian Treasuries (HOTS) Forum which meets periodically. While the resulting Commission reports are provided formally to the Commonwealth Government, they are made available to the states immediately thereafter. The relativities recommended in those reports are considered at the Annual Treasurers' Conference. The Commission's relativities are almost always accepted by the Treasurers' Conference as preliminary relativities are publicly defended by the Commission in open adversarial proceedings in all states prior to their formal presentation. Only in 1981 ( the Commission was asked to re-do the relativities and present a new report in 1982) and in 1982 the Commonwealth Government chose not to accept the Commission's recommendation but instead the Premiers' Council under the leadership of Prime Minister J.M. Fraser (Commonwealth Treasurer, J.M. Howard) adopted relativities different from those recommended by the Commission for the years 1982-1984 (see Commonwealth of Australia, 1995, pp.137-158 ) .

\section{The Finance Commissions of India}

The Finance Commissions of India comprising a chair and four members are constituted by the President every five years to meet the constitutional requirement (under Article 280 of the Constitution of India, 1949 as amended in 1992 and 1993) to redress the fiscal gaps in the revenues and expenditures of the Union (federal) and State governments arising out of a mismatch of revenue means and expenditure needs at various levels. The Finance Commission is mandated to make recommendations to the President as to:

(a) the distribution between the Union and the States of net proceeds of taxes which are to be, or may be, divided between them and the allocation between the states of the respective shares of such proceeds;

(b) the principles which should govern the grants-in-aid of the revenues of the States out of the Consolidated Fund of India;

(c) the measures needed to augment the Consolidated Fund of a State to supplement the resources of the Panchayats in the State on the basis of the recommendations made by the Finance Commission of the State; 
(d) the measures needed to augment the Consolidated Fund of a State to supplement the resources of the Municipalities in the State on the basis of the recommendations made by the Finance Commission of the State; and

(e) any other matter referred to the Commission by the President in the interests of sound finance. achieve this through revenue sharing and special grants to needy states. The Commission is also required to recommend allocation among states of their share of federal taxes.

The first Finance Commission was established in 1951 by an act of parliament, the Finance Commission (Miscellaneous Provisions) Act, 1951 (Act XXXIII of 1951). Subsequently, these commissions have been reconstituted every five years with new terms of reference for the next quinquenniel period. According to the 1951 Act, the chairperson of the Commission must have experience in public affairs members may be selected from among persons who: (a) are, or have been, or qualified to be appointed as judges of a High Court; or (b) have special knowledge of the Finances and Accounts of the Government; (c) have had wide experience in financial matters and in administration; or (d) have special knowledge of economics. The Commission members are usually a mix of politicians, retired civil servants and experts in fiscal federalism. Each Commission creates a temporary secretariat managed by a secretary appointed by the federal government usually from the Planning Commission. The Commission is disbanded upon submission of a report consistent with its terms of reference. The Commission does not have the mandate to initiate an inquiry outside its terms of references. The Commission's recommendations are not binding upon the government but under article 281 of the Constitution, these must be presented to both houses of the parliament along with government response to each recommendation.

\section{Fiscal and Financial Commission (FFC) of the Republic of South Africa}

The FFC was established in 1993 under section 198 of the 1993 interim Constitution. The commission was to have 18 members appointed by the President with nine members designated one each by nine provincial cabinets. The interim Constitution gave a broad mandate to the Commission in providing advice on financial and fiscal requirements of the national provincial and local governments (section 199(1)(a)). The Final Constitution of 1996 expanded the Commission membership to 22 by adding two representatives from the organized local government structure and two additional presidential appointments. Such a large membership was subsequently seen as unwieldy and an amendment to the Constitution carried out in 2001 (The Constitution of the Republic of South Africa Second Amendment Act, 2001, section 7) reduced the Commission membership to the current strength of nine to be appointed by the President in consultation with the Cabinet and Executive Councils of the nine provinces as follows:

- A chairperson and a Deputy Chairperson

- Three members recommended by provincial premiers;

- Two members recommended by local governments; and

- Two other members.

The 1996 Constitution (section 214(1)) narrowed Commission's mandate to provide advice on equitable allocation of central revenue sharing to provincial and local 
governments; provincial taxation; municipal fiscal powers and function; sub-national borrowing and central government guarantees (sections 218(2), 228(2)(b), 229(5) and 230(2)). The role of the Commission was further clarified by Central legislation. The Borrowing Powers of Provincial Governments Act, 1966 authorized the Minister of Financed to seek Commission's advice on provincial borrowing and debt management issues. The Provincial Tax Regulation Process Act, 2001 empowers the Commission to provide comments on tax proposals by the provinces.

The Intergovernmental Fiscal Relations Act, 1997 clarified the institutional arrangements and the processes for the Commissions' advice to executive and legislative organs. The Commission was given an observer status at the Budget Council, a forum of the Ministers of Finance of Center and the Provinces. Further the Act requires the Commission to provide advice on equitable shares at least 10 months prior to the commencement of the fiscal year and the Division of Revenue Bill must include comments by the national government on the Commission's recommendation. Overall the Commission enjoys a strong constitutional-legal foundation to play role of an influential advisor on intergovernmental fiscal relations. This role was carefully crafted to ensure that "it can bark, but not bite” (Wehner, 2003, p.5).

\section{Uganda: Local Government Finance Commission}

The Local Government Finance Commission of Uganda is mandated under the 1995 Constitution (article 194(1,4)) and the Local Government Finance Act, 2003 (section 9) to serve as an advisory body to national government (Minister of Local Government) on all matters relating to transfer of resources to local government and to advise local governments on appropriate levels of local revenues. It is expected to recommend both the total pool of transfers as well as allocations to local governments in the form of equalization and conditional grants. In addition, it monitors compliance of local governments with legal requirements associated with their taxing and spending decisions. It is also empowered to mediate financial disputes among local governments.

The Commission consists of seven commissioners appointed by the President as follows:

- Three commissioners nominated by the district councils through the Uganda Local Authorities Association;

- One commissioner nominated by the Urban Councils through Urban Authorities Association of Uganda;

- Three commissioners nominated by the Minister of Local Government in consultation with the Minister of Finance, Planning and Economic Development.

The President designates two of the commissioners as Chairperson and Deputy Chairperson who work on a full time basis. The rest of the commissioners serve on a part-time basis only. A permanent secretariat headed by a secretary with 31 staff conducts the day-to-day business of the Commission. 


\section{A New Institutional Economics (NIE) Framework for Evaluating Alternative Institutional Arrangements for Equalization Transfers}

The previous section noted diverse institutional arrangements are used for decision making on central-state-local transfers. There is, however, no framework available in the literature to provide a comparative evaluation of these arrangements to guide future reform efforts. This section attempts to fill this void by borrowing ideas and concepts from a relatively new discipline of neo-institutional economics (see North, 1990). Under the NIE framework both the principals and their agents act rationally in their own selfinterest. The access to information is costly and not uniformly available to all. In such circumstances, the agent may not secure the interests of their principals and the principals may not be able to restrain opportunistic behaviors of their agents due to the "bounded rationality" of principals and high transactions costs associated in overcoming this handicap.

In the context of institutional arrangements for a fiscal equalization program, the problem manifests itself as follows. First, there needs to be national compact on equalization principles and standards so that there is a clear view on the mandate given by principals (citizens). This compact can take the form a constitutional provision, legislative enactment or an informal but universally shared consensus on the goals of such a program. This compact, however, will have to be administered by various public agents e.g. executive and legislative organs typically at the national level. Such administration may entail commitment problems where it may be in the self interest of some agents not to follow the compact. For example, the national executive or legislative leadership may come from a region with little enthusiasm for interstate equity. Alternately current regime is committed but unable to tie the hands of future regimes and thereby durability of the compact is threatened. Enshrining of equalization principles in the constitution is often motivated by these considerations. But constitutional enshrinement limits the commitment problem but does not overcome it as current coalitions can be replaced by coalitions of opposing interests and policy preferences in the future ${ }^{\mathrm{ii}}$.

Institutional arrangements for administering the compact also entail a number of transactions costs for principals and their agents. For principals various types of arrangements impose differential participation and monitoring costs (PMC). There are also costs associated with legislative (LC) and executive decision making (EDMC). These costs are the time and effort needed to strike a legislative compromise or an executive decision. They are higher when stakes for individual parties are high and when there are strong conflicts of interest and when there is some uncertainty as to the future revenue streams available to donor and recipient governments - a frequently recurring situation in negotiations on fiscal transfers. All institutional arrangements entail costs incurred by principals to induce compliance by their administrative agents with the compact, the so-called agency costs (AC). Agency costs arise as the administrative agents to implement the compact on behalf of the principals may not share the objectives pursued by the principals. They may undertake decisions to serve narrow self interest of bureaucratic power or personal enrichment and because of the high transactions costs, civil society or the legislature may not be able to exercise effective oversight on these 
decisions. In view of the difficulty of monitoring and taking corrective action ex-post, legislatures typically try to influence the appointment of executives so that they share the same goal and would not undermine the enacted legislation. In addition, they rely much more on civil society monitoring and respond to "fire alarms" raised by unhappy constituents (Horn, 1997, p.21). But such response to fire alarms may be constrained if the executive agency is given a significant degree of autonomy ${ }^{\mathrm{iii}}$. Finally, there also risks and uncertainty costs (UC) associated with unstable regimes. Risks and uncertainty in fiscal relations, arises because both the potential benefits and costs of a given compact may not be fully known at the time a deal is struck. In the future, such a deal may be undone by a new coalition and constellation of interests.

The analytical framework described above argues for instituting administrative arrangements and governance structures that (a) facilitate greater access to information by citizens, interested sectors of civil society (including the media and academics) and legislators that would enable them to better hold those agents involved in equalization

decision-making to account; (b) minimize transaction costs associated with participation, monitoring and decision making, agency costs (costs incurred by principals and other agents to ensure that agents involved in equalization decision-making act faithfully to serve their mandates) and uncertainty costs; and (c) create an incentive structure for both the legislative and administrative agents to comply with their compact with the principals.

This is a rather complex task because of interdependencies associated with various actions. For example, as pointed out by Horn (1997, p.24), attempt to reduce agency loss between citizens and legislatures through restraining the influence of legislatures on the executive may potentially increase agency losses between legislatures and government executives. There are further difficulties in ensuring durability of legislation which can be undermined through lack of effective enforcement even if the legislation remains unchanged.

\section{Comparative Evaluation of Alternate Institutional Arrangements using NIE Framework}

An earlier section highlighted four stylized types of institutional arrangements. A central government agency model represents one of the most prevalent arrangements. A national legislature model represents the least common of these arrangements. The first arrangement rests decision making solely in the hands of a central government agency and the second arrangement involves the legislature not just in legislation but also in executive decision making role. Other interesting options for institutional arrangements are represented by intergovernmental forums and independent agency models. In the following analytical comparisons of the two common options are made using the NIE framework. It must be noted at the outset that these two options are not necessarily exclusive choices and both arrangements can co-exist, but when they do, incremental value added offered by the independent agency must be rigorously examined. 
Intergovernmental Forums: An intergovernmental forum provides a framework for institutionalized but restricted political bargaining ${ }^{\mathrm{iv}}$. Bargaining is restricted as the constitution and the legal framework usually define the limits to such bargaining. There is, however, strong peer pressure to strike a bargain. Thus intergovernmental forums are usually successful in defining an explicit political compact acceptable to all parties. As such a political compact cannot be easily reached when complex criteria are put on the table, this institutional model places great premium on simplicity and "rough justice" as opposed to complex but precise justice. Conflicting interests are represented at these forums. Unless the discussions of the forum are conducted in camera, political grandstanding may prevent political compromises. Durability of such compromises is usually assured as all parties stand to loose from a deal that is unraveled. Blame shifting is also not possible as the members of the forum assume full responsibility for their decisions. The forum further enables participating governments representing competing interests and varying commitments on equalization, to reach a broader consensus.

Independent Agency (grants commission) model: An independent agency is usually established to seek an independent, professional, transparent and rigorous view of a complex task of developing recommendations on the determination of the pool, the allocation criteria and distribution of funds among recipient governments. The presumption here is that if such a decision is divorced from politics, the resulting criteria and the associated distribution would serve the broader interests of the nation as well as its constituent units better. These theoretical advantages are rarely achieved in practice. First, decisions on the standard of equalization e.g. the minimum level of per capita fiscal capacity to which all jurisdictions are entitled to be brought up to, cannot and should not be divorced from politics. Second, such an institutional arrangement creates a number of agency problems as discussed below.

Mission creep: To secure its long term existence and enlarge its spheres of influence, an independent agency faces continuous imperatives reinterpreting its terms of reference to enlarge the scope of its activities. Such a mission creep goes unchecked as the politician do not want to be seen curtailing the search of such agencies for a holy grail - the ultimate formula for equitable distribution of federal funds.

Incentives for complexity: An independent agency faces powerful incentives to seek ever more complex solutions to simple questions. This is because complexity and associated expertise fuels demand in the external market for professionals serving these agencies. The greater the complexity of formulae and associated calculations, greater is the premium placed by the market on professional possessing those skills. Interested parties submissions makes it politically imperative to accommodate ever growing complexity. Outside academic experts typically clamor for further complexity to achieve more precise justice. There is no escape from this circle as part time or term employment of members of the commission limits the oversight provided by them. It takes sometime for term members to grasp the complexity of the allocation rules and by the time they can form their own judgment on their relative merits, it is usually time for them to say good bye. In any case, the staff would be resistant to any simplification and those recipient 
governments who benefit from the complexity and associated inequities of the system will likely block any reforms. Independent think tanks and researchers may even call for greater complexity to bring practice in conformity with the theory. In conclusion, constraining influences to keep the system simple and easily comprehensible are stunted by the very existence of an independent agency.

Fire alarm oversight impractical and costly: Citizen oversight of such independent agencies becomes infeasible for several reasons. First, more complex the distribution criteria suggested by the agency, the more difficult it is for individual citizens and civil society groups to make informed comments. Further conflicting representation by various citizen groups trying to secure local interests strengthens broad discretion granted to such agencies in the interest of a scientific a-political approach. Even "fire alarm" oversight sought by legislatures becomes too costly and impractical as unhappy constituents make conflicting demands on their representatives.

\section{Tentative conclusions on a comparative evaluation of intergovernmental forum vs. independent agency model}

The above discussion suggests that the ultimate decision on relative merits of each institutional arrangement must be guided by an analysis of the incentive regime created by each institutional set-up and associated agency costs and their success in achieving simple, equitable and durable outcomes. Table 1 presents a comparative NIE perspective on these arrangements. The NIE framework predicts that overall transactions costs are expected to be higher and potential outcomes less desirable under an independent agency model as compared to an intergovernmental forum. These results stem from the fact that independence and autonomy offered to grant commissions weaken citizen oversight. Their drive for optimal (ideal) systems invites complexity and undermine transparency and accountability. Thus participation and monitoring costs as well agency costs rise. Intergovernmental forums on the other hand look for simple and feasible alternatives to strike a political bargain and thereby reduce transactions costs for the nation as whole. Higher transactions costs under independent grants commission nevertheless are not expected to secure better outcomes. On the other hand grants commission processes do not necessarily encourage consensus building that is achieved by forging a political compact on equalization standard. In the absence of a political compact on the equalization standard both the pool and allocation among constituent units, are determined quite independently of that equalization standard. Stability of allocation criteria is also not assured by a grants commission as the desire for perfection may lead to frequent changes in the methodology. In summary, the independent grant commission is a poor substitute for an intergovernmental forum. Its usefulness as a complementary institution to an intergovernmental forum is also quite limited in view of high agency costs and its pre-disposition towards optimal as opposed to feasible reforms.

\section{Why Then Are Independent Agencies (Grant Commissions) So Popular?}

The NIE framework suggests that independent grant commission may not represent a better institutional choice in view of the incentives regimes created by the underlying 
structures. These conclusions run counter to predominant view in the fiscal federalism literature that such institutions personify "best practices" in institutional arrangements. In fact, it is quite commonplace for international development agencies and leading consultants to recommend establishment of such commissions in developing and transition economies (see Searle, 2004, Boex and Martinez-Vasquez, 2004). For a NIE analyst such popularity is not surprising if one looks at the incentive structure and culture of these institutions. Independent agencies find strong support among academic scholars, think tanks and politicians by playing to the enlightened self-interest of these groups. These agencies cater to "elites" especially academic elites as they give them a forum for dissemination of their research and scholarly works. The agencies are perceived to be apolitical pursuing technical excellence. Further they support the consulting industry by seeking their advice and analysis. These agencies serve as convenient tools for national and regional politicians as they are seen to be providing fair, balanced and professionally rigorous analysis. For any unpopular distribution criteria, politicians have the ability to distance themselves from the analysis and instead shift blame on the agency. Further, they can avoid taking hard decisions and simply accept the agency's view as a "take it or leave it” proposition. No wonder one finds a growing chorus of professional and political views advocating independent agency approach to vital decisions on equalization transfers.

\section{From Theory to Practice: Do NIE Predictions Hold Water?}

The previous section presented in abstract a comparative analytical perspective on the working of intergovernmental forums and independent grants commissions. This section explores the same concepts based upon experiences of Canada and Germany with intergovernmental forums and of Australia and India with independent grant commissions. Note that we have abstracted from the complexity in Australia that the independent grant commission works as a complement to the intergovernmental forum (HOTS Forum). This abstraction should not bias our analysis as the recent history of the CGC in Australia demonstrates that it has enjoyed significant independence and autonomy and its recommendations have almost always been accepted by the Federal Cabinet.

Table 2 reflects upon comparative experiences using NIE framework. Briefly the following lessons can be drawn from these experiences:

Transactions Costs: The institutional arrangements in the four case study countries incur differential citizen participation and monitoring costs, agency costs and uncertainty costs. Intergovernmental forums typically lead to lower transactions costs for the principals (citizens) primarily due to greater transparency, simplicity and media and civil society scrutiny of programs. Agency costs are highest under the Australian program due to greater autonomy and incentives for complexity and mission creep faced by the CGC staff. The periodic grants commission in India has medium agency costs as it is constrained by its limited duration tenure. Legislative and executive decision making costs are very similar across case study countries. Overall intergovernmental forums 
appear to offer less costly alternatives for the principals to induce compliance from their agents.

Outcomes: Program outcomes are to be judged for clarity of mandate by the principals, durability of political consensus and for simplicity and equity of the equalization transfers programs. Equalization programs in Canada and Germany are enshrined in their constitutions. The Australian program is mandated by federal law and the Indian program is primarily concerned with equitable distribution of federal revenue sharing pool and has no explicit equalization objective.

There is a reasonable degree of political consensus on the principles of equalization in Canada, Germany and Australia. No such consensus has yet emerged in India. What distinguishes Canadian and German programs from those of Australia and India are clarity of the equalization standard and simplicity in implementing it. Needless to say both these programs have a number of shortcomings (see Shah, 2003). The Australian and Indian programs lack clarity in equalization standard.

Australia uses a comprehensive program attempting to equalize fiscal capacity as well as fiscal needs requiring highly complex calculations. Massive amounts of data are analyzed to calculate revenue disability for 18 tax bases and expenditure disabilities for 40 programs with countless relevant determinants. The procedures used are so complex that the Australian program is a black box even for a serious student. The program thrust is on absolute comparability of services across states and territories. This focus diverts states' energies to proving that "they need more to do less" as opposed to "doing more with less". While the overall approach to expenditure needs is sound and defensible, the pursuit of idealism by the CGC and constant refinements lead to super complexity and non-transparency. For highly correlated factors disabilities are artificially magnified through double counting and multiplication. Under such a program use of judgment on factors and weights is inevitable but such judgments invite controversy and compromise the credibility of the whole program. When all is said and done the results are often disappointing. As the program lacks an explicit equalization standard, its generosity is overwhelming for its Northern Territory , Tasmania and South Australia and the program is punitive for Victoria and New South Wales. The program, however is not equitable and grant allocations vary directly with most macro fiscal capacity indicators (see Shah, 2004, for a detailed critique of the Australian Program and suggestions for simplification). The Indian formula is less complex but uses arbitrary factors and weights. Curiously enough all recent commissions have insisted on using 1971 state population figures for calculation of grant shares. The rationale presented is that India adopted a population control policy in that year. This is not defensible as the state population has experienced major changes due to migration.

\section{Concluding Remarks}

Comparing institutional arrangements across different countries is a daunting task. The success of these arrangements depends upon a multitude of factors. The success of 
governance structures for fiscal matters may depend not only on the incentives regime associated with their inner structures but also their interactions with other formal and informal institutions in the country. This paper presented a simple framework to understand these incentives and interactions and draw implications for their impacts on transactions costs for the society as a whole and achievement of societal objectives. An application of these concepts to the specific case of institutional arrangements for fiscal equalization transfers was carried out and the predictions based upon the theory were compared to observed experiences in major federal countries. The paper demonstrates that the simple new institutional framework presented here has significant power for predicting potential impacts. The paper concludes, both in theory and practice, that the case for an independent grants commission to enhance the transparency, equity and accountability of the intergovernmental finance system is vastly exaggerated. 


\section{References}

Boadway, Robin and Anwar Shah (forthcoming). Fiscal Federalism: Principles and Practices. New York and London: Cambridge University Press

Boex, James and Jorge Martinez-Vasquez (2004). Developing the Institutional Framework for Intergovernmental Fiscal Relations in Decentralizing LDCs. Georgia State University, Atlanta, Georgia.

Commonwealth of Australia (1995). Equality in Diversity: History of the Commonwealth Grants Commission. Second Edition. Canberra: Australian Government Printing Service.

Government of India, $12^{\text {th }}$ Finance Commission (2003). Fifty Years of Fiscal Federalism

- Finance Commissions of India. New Delhi: Government of India.

Horn, Murray J. (1997). The Political Economy of Public Administration. New York, USA: Cambridge University Press.

North, Douglas (1990). Institutions, Institutional Change and Economic Performance. Cambridge, UK: Cambridge University Press.

Peloquin, David (2005). Backgrounder on Equalization and TFF Governance Issues. Department of Finance, Canada, Ottawa.

Searle, Bob. (2004) Institutional Aspects of the Balancing Fund, Ministry of Finance, Indonesia, December 2004.

Shah, Anwar (2004). The Australian Horizontal Fiscal Equalization Program in the International Context. Presentation at the Commonwealth Grants Commission, Canberra, Australia, September 23, 2004.

Shah, Anwar (2003). Lessons From The Theory and Practice of Intergovernmental Transfers. World Bank.

Shah, Anwar (1991). The New Fiscal Federalism in Brazil. World Bank Discussion Paper No. 124. Washington, DC: World Bank.

Uganda, the Republic of (2004). Local Government Finance Commission, Corporate Strategy, 2004-2008. Kampala, Uganda.

Wehner, Joachim (2003). The Institutional Politics of Revenue Sharing in South Africa. Regional and Federal Studies, Vol. 13, No. 1 (Spring): 1-30. 
Figure 1 (a)

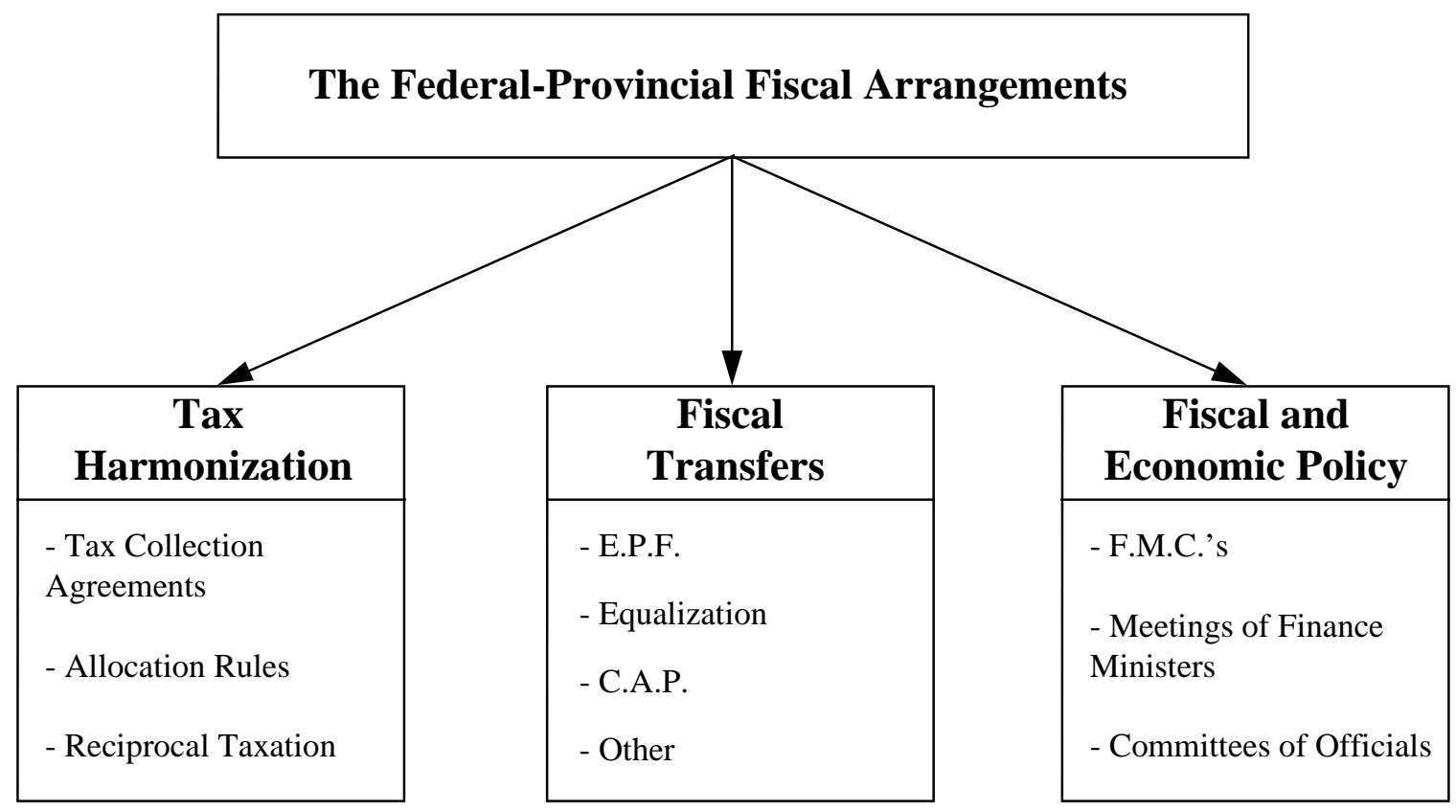


Figure 1 (b)

\section{Federal-Provincial Fiscal Arrangements Committees}

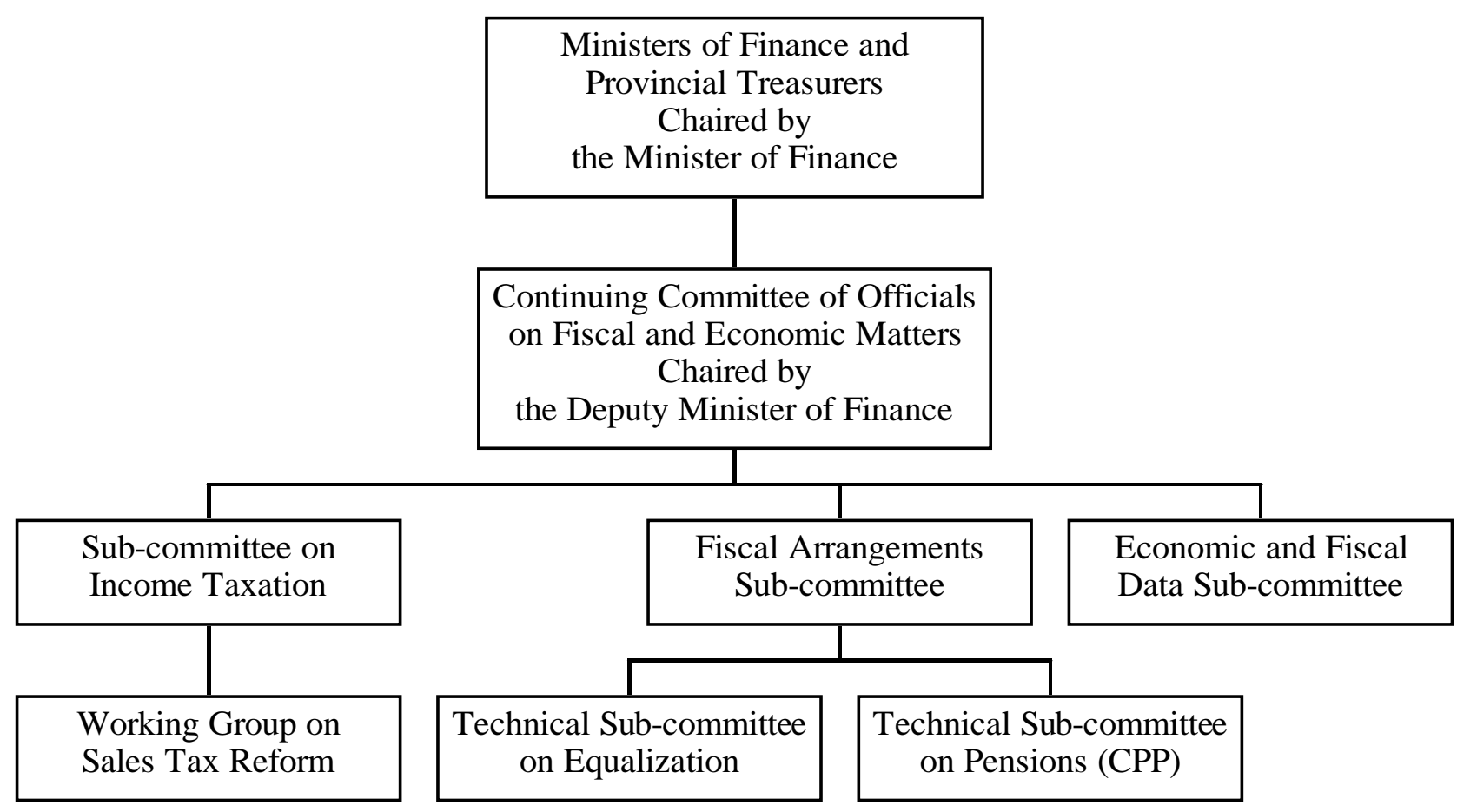




\begin{tabular}{|c|c|c|}
\hline \multicolumn{2}{|c|}{$\begin{array}{l}\text { Table 1. Comparative Conceptual Evaluation of } \\
\text { Intergovernmental Forum vs. Independent Agency (Grant } \\
\text { Commission) }\end{array}$} & \multirow[b]{2}{*}{ IA } \\
\hline & IGF & \\
\hline $\begin{array}{l}\text { Transactions costs (overall): } \\
\text { - } \quad \text { Participation and monitoring costs } \\
\text { - } \quad \text { Legislative and executive decision making } \\
\text { - } \text { costs } \\
\text { - } \text { Agency costs } \\
\text { Uncertainty costs }\end{array}$ & $\begin{array}{l}\text { Low to medium } \\
\text { High } \\
\text { Low } \\
\text { Low }\end{array}$ & $\begin{array}{l}\text { Low to high } \\
\text { High } \\
\text { High } \\
\text { Medium }\end{array}$ \\
\hline $\begin{array}{l}\text { Potential outcomes } \\
\text { - Political compact on equalization standard } \\
\text { - Durability of political compact } \\
\text { - Pool determined by equalization standard } \\
\text { - Allocation determined by equalization } \\
\text { - Standard } \\
\text { Stability of allocation criteria }\end{array}$ & $\begin{array}{l}\text { Yes } \\
\text { Yes } \\
\text { Yes/No } \\
\text { Yes } \\
\text { Yes }\end{array}$ & $\begin{array}{l}\text { No } \\
\text { NA } \\
\text { No } \\
\text { No } \\
\text { May be }\end{array}$ \\
\hline
\end{tabular}

Source: Author's calculations 


\begin{tabular}{|c|c|c|c|c|}
\hline \multicolumn{2}{|c|}{$\begin{array}{l}\text { Table 2. Equalization Programs - } \\
\text { Comparative Experiences with } \\
\text { Intergovernmental Forum (IGF) vs. } \\
\text { Independent Agency ( Grant Commission) } \\
\text { (IA) }\end{array}$} & & & \\
\hline & IGF & IGF & IA & IA \\
\hline & Canada & Germany & Australia & India \\
\hline $\begin{array}{l}\text { Transactions costs (overall): } \\
\text { - } \text { Citizen participation and } \\
\text { monitoring costs } \\
\text { - } \text { Legislative costs } \\
\text { - } \\
\text { Executive decision making } \\
\text { - } \text { Costs } \\
\text { - } \\
\text { Agency costs } \\
\text { Uncertainty costs }\end{array}$ & $\begin{array}{l}\text { Low } \\
\text { Low } \\
\text { Medium } \\
\text { Low } \\
\text { Low }\end{array}$ & $\begin{array}{l}\text { Medium } \\
\text { Low } \\
\text { Medium } \\
\text { Low } \\
\text { Low }\end{array}$ & $\begin{array}{l}\text { High } \\
\text { Low } \\
\text { Medium } \\
\text { High } \\
\text { Medium }\end{array}$ & $\begin{array}{l}\text { High } \\
\text { Low } \\
\text { Medium } \\
\text { Medium } \\
\text { Medium }\end{array}$ \\
\hline $\begin{array}{l}\text { Outcomes } \\
\text { - } \text { Political consensus on } \\
\text { - } \text { equalization } \\
\text { - } \text { Political compact on } \\
\text { equalization standard } \\
\text { - Type of equalization program } \\
\text { - Pool determined by } \\
\text { - } \text { equalization standard } \\
\text { - } \text { equalization determined by } \\
\text { - Fiscal capacity equalization } \\
\text { - } \text { Fiscal need equalization } \\
\text { - Stability of allocation criteria } \\
\text { - } \text { Sunset clause } \\
\text { Dispute resolution }\end{array}$ & $\begin{array}{l}\text { Yes, Const. } \\
\text { Yes } \\
\text { Const. } \\
\text { Paternal } \\
\text { Yes } \\
\text { Yes } \\
\text { Yes, RTS } \\
\text { No } \\
\text { Yes } \\
\text { Yes } \\
\text { Supreme } \\
\text { Court } \\
\text { Yes }\end{array}$ & $\begin{array}{l}\text { Yes, } \\
\text { Const. } \\
\text { Yes } \\
\text { Solidarity } \\
\text { pact } \\
\text { Fraternal } \\
\text { Yes } \\
\text { Yes } \\
\text { Yes, Act. } \\
\text { Revenues } \\
\text { No } \\
\text { Yes } \\
\text { No } \\
\text { Const. } \\
\text { Court } \\
\text { Yes }\end{array}$ & $\begin{array}{l}\text { Yes, fed. } \\
\text { law } \\
\text { Yes } \\
\text { No } \\
\text { Paternal } \\
\text { No } \\
\text { No but } \\
\text { formula } \\
\text { Yes, } \\
\text { RTS } \\
\text { Yes } \\
\text { No } \\
\text { No } \\
\text { Supreme } \\
\text { Court } \\
\text { May be? }\end{array}$ & $\begin{array}{l}\text { No } \\
\text { No } \\
\text { No } \\
\text { Paternal } \\
\text { No } \\
\text { No } \\
\text { No } \\
\text { Yes, some } \\
\text { No } \\
\text { No } \\
\text { Supreme } \\
\text { Court } \\
\text { May be? }\end{array}$ \\
\hline
\end{tabular}

Source: Author's perspectives 


\section{NOTES}

${ }^{\mathrm{i}}$ This paper draws heavily on Boadway and Shah (forthcoming). Earlier versions of this paper were presented at the meetings of the Government of Canada Experts' Panel on Fiscal Equalization, Montreal, Canada, September 1, 2005 and at the Conference on Intergovernmental Fiscal Transfers at the Georgia State University, Atlanta, Georgia from October 3-5, 2004. The views expressed in this paper are those of the author alone and should not be attributed to the World Bank. The author is grateful to Robin Boadway, Roy Bahl, Richard Bird, Jamie Boex, Fred Gorbet, Jorge Martinez, David Peloquin, and Bob Searle for comments.

ii It should be noted that the cast of "agents of the citizenry" is potentially much broader than just the "executive and legislative organs" of the central government. These agents through intergovernmental competition - especially among states/provinces - and of players from civil society, can help ensure transparent self-regulation of any equalization governance regime through a system of checks and balances that minimizes the risk of "capture" and the resulting domination of a narrow set of more-or-less private interests in the governance regime.

iii In his comments on this paper, David Peloquin has argued that it is not immediately clear who the "unhappy constituents" may be in the equalization context: presumably, it is provincial/state governments who are most likely to first raise "fire alarms" and then go about drumming up secondary alarms on the part of local civil society actors and the local citizenry (as recent Canadian experience demonstrates only too well...). Since provinces/states are the very same prime stakeholders who would be the main clients and interveners of any autonomous grants agency, it is not clear that the latter could in any sense be indifferent to them, given the quite credible threat of "going public" and appreciably raising the political and electoral stakes when they suspect their interests are not being given fair consideration.

${ }^{\text {iv }}$ Note these restrictions should not be such as to reduce political bargaining to a zero sum game as under such a scenario, benefits of a federal bargain will be significantly curtailed. 